症例

腸間膜から発生した粘液性襄胞腺腫の 1 例

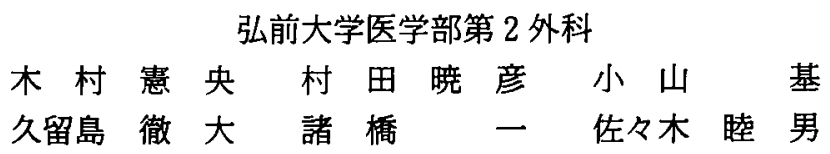

症例は51歳，女性，右下腹部痛を主訴に近医を受診した．腹部 CT で回盲部から腸間 膜にかけて内部が均一で造影効果を認めない約 $10 \mathrm{~cm}$ 径の衰胞性腫崵を指摘され，当科 一紹介入院となった。大腸内視鏡検查では粘膜病変や壁外性の圧排所見はみられなかっ た. 血管造影検査では回盲部の無血管領域が認められた．以上の所見から腸間膜リンパ 管腫の疑いで，開腹手術を施行した．腫場は $9 \times 8 \times 7 \mathrm{~cm}$ 径で回盲部の腸間膜に存在 し, 回腸と高度に癁着しており, 回腸 $100 \mathrm{~cm}$ を含む回盲部切除術を施行した. 切除標本 は一部に多房性部分の混在する哄胞性腫場で，緑色粘液性の内溶液を含んでいた。病理 組織学的には粘液豪胞腺腫と診断され，免疫染色で ER, PgR, CA125が陽性であり,女 性生殖器由来の腫場と推測された。その由来としては異所性卵巣や二次性ミュラー管組 織が考えられた，非常に稀な腸間膜原発の粘液性豪胞腺腫の 1 例を経験したので，若干 の文献的考察を加え報告する.

索引用語：腸間膜腫揚, 粘液性塞胞腺腫

\section{緒 言}

腸間膜原発腫瘍は比較的稀な疾患であるが，その中 でも腸間膜原発の粘液性豪胞腺腫は非常に稀な疾患 て，本邦の報告例はみられていない，今回，回盲部小 腸間膜に発生した粘液性咅胞腺腫の 1 例を経験したの で，若干の文献的考察を加え報告する。

$$
\text { 症例 }
$$

患者：51歳，女性.

主訴：右下腹部痛.

家族歴：特記事項なし。

既往歴: 平成 5 年より統合失調症.

現病歴：平成15年 9 月21日右下腹部痛が出現したた め近医を受診し, 腹部 CT で右下腹部に約 $10 \mathrm{~cm}$ 径の 哓胞性腫瘍を指摘された。10月15日精査加療を目的に 当科へ紹介受診となり，11月18日手術目的に入院とな った。

入院時現症：身長 $149.8 \mathrm{~cm}$, 体重 $89.4 \mathrm{~kg}, \mathrm{BMI} 39.8$ と高度肥満. 眼睑眼球結膜に貧血, 黄㾝を認めなかっ

2005 年 4 月 13 日受付 2005 年 7 月 5 日採用

〈所属施設住所〉

干036-8562 弘前市在府町 5
た。右下腹部に小児頭大の弾性硬の腫瘤を触知し, 軽 度の圧痛を認めた。

入院時検查成績: 末梢血, 血液生化学検查に異常は 認めなかった。腫瘍マーカーの CEA, CA19-9, AFP はすべて正常範囲内であったが，CA125 のみが104U/ $\mathrm{ml}$ と高値であった.

腹部超音波検查：右下腹部に $9 \times 8 \times 7 \mathrm{~cm}$ 径の内 部は均一で低エコーな衰胞性病変を認め, 暻胞内の一 部に高エコーな充実性成分がみられた（図 1 )。

腹部単純 $\mathrm{X}$ 線写真：右下腹部に $11 \times 8 \mathrm{~cm}$ 大の腫 瘍陰影による透過性の低下が認められた。

大腸内視鏡検查：大腸内腔に粘膜病変や，壁外性の 圧排所見は認めなかった。

腹部 CT 検查：回盲部から腸間膜にかけて約 $10 \mathrm{~cm}$ 径の撉胞性腫場が認められた。腫煌辺緑が被膜様に淡 く造影され，内部は均一で造影効果は認められなかっ た。腫瘍の一部には結節状の充実性成分がみられた(図 2).

血管造影検査：回盲部に無血管領域が認められ，同 部位での回結腸動脈分枝, 回腸動脈の圧排がみられた。 栄養血管は明らかではなかった。

臨床経過：以上の所見より，腸間膜原発の亮胞性腫 


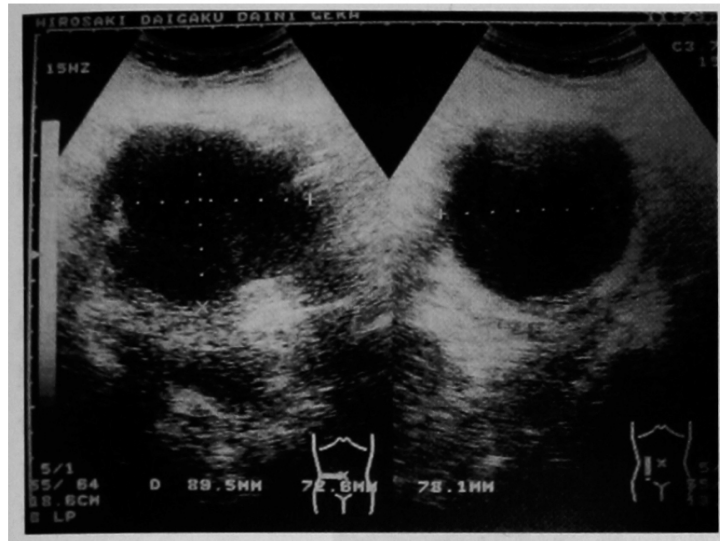

図 1 㖟部超音波検查：右下腹部に $9 \times 8 \times 7 \mathrm{~cm}$ 径の

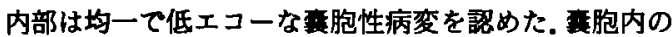
一部に高エコーな充実性成分がみられた。

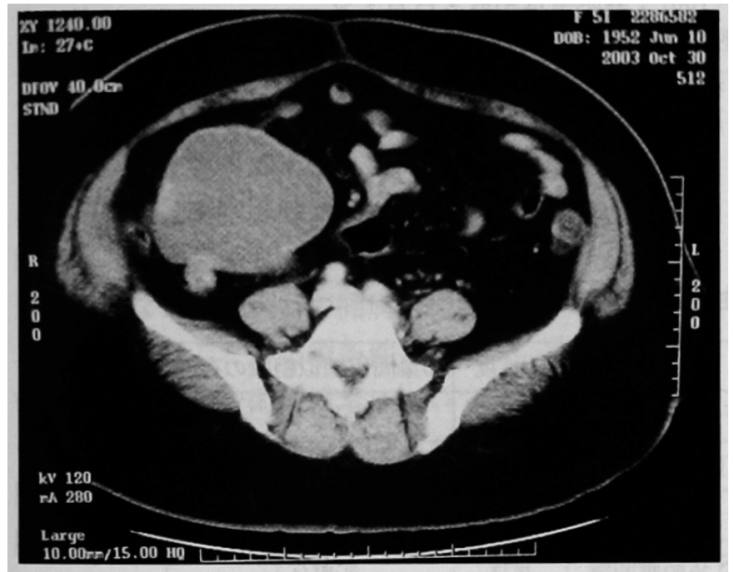

図 2 腹部 CT 検查：回盲部から腸間膜にかけて約 $10 \mathrm{~cm}$

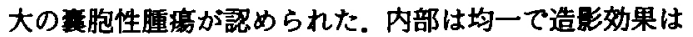
認められなかった。一部に結節状の充実性成分がみられ た.

瘍，その中でも腸間膜リンパ管腫が強く疑われた．充 実性成分が混在していることから悪性病変の可能性も 否定できず，11月28日開腹手術を施行した.

手術所見：腫瘍直上の右下腹部に約 $15 \mathrm{~cm}$ の横切開 をおき開腹した。腫瘍は回盲部小腸間膜に存在し，大 網や小腸と強固に结着していたが, 小腸に狭窄や拡張 は認めなかった。腫崲と後腹膜, 両側卵巣, 虫垂との 境界は明暸であり,腸間膜原発の腫場と考えられた(図 $3 \mathrm{a})$. 悪性の可能性も否定できず, 瘾着した回腸 100 $\mathrm{cm}$ を含む回盲部切除を施行した。

摘出標本肉眼所見：腫蝪の大きさ $9 \times 8 \times 7$
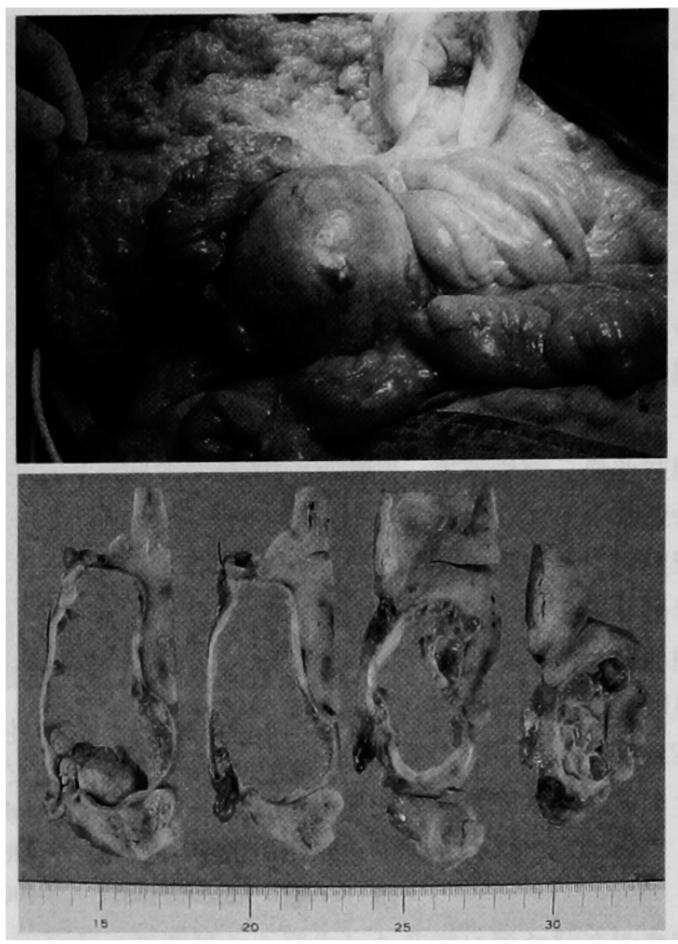

图 3 a 手術所見：腫痀は回盲部腸間膜に存在し,大 網，小腸と強固に痋着していた。

b 摘出標本肉眼所見：腫㾀割面は一部に多房 性成分を有する竞胞性腫癔であった。

$\frac{\mathbf{a}}{\mathrm{b}}$

$\mathrm{cm}$, 白色，表面平滑，弾性硬，辺縁は明瞭て，大網お よび回腸の 3 力所で痹着していたが，腸管腔内への浸 潤所見は認めなかった，畽暚内容物は緑色で粘調な液 体であった。また，腫鹪割面の所見では，一部に充実 性成分や多房性成分を有する集胞性腫場であった（図 3 b).

病理組織所見 (H-E 染色)：腫瘄は多房性の畺胞性 病変で，整胞壁は粘液を産生する単層立方上皮であっ た．間質は硝子化，線維化の結合織が主体であり，一 部に卵巣間質類似細胞，平滑筋細胞を有していた。覀 性を示唆する細胞は認めず，粘液性真胞腺腫と診断さ れた（図 4 a).

病理組織所見 (兔度染色)：ER (図 4 b), PgR (図 $4 \mathrm{c}$ ), CA125 (図 $4 \mathrm{~d}$ ) が陽性であり, 女性生殖器由 来の腫瘍と推測された。

術後経過：術後経過は順調で術後13日目に退院し た. 1 年以上を経過した現在も外来で経過観察中であ るが，再発を認めていない。 

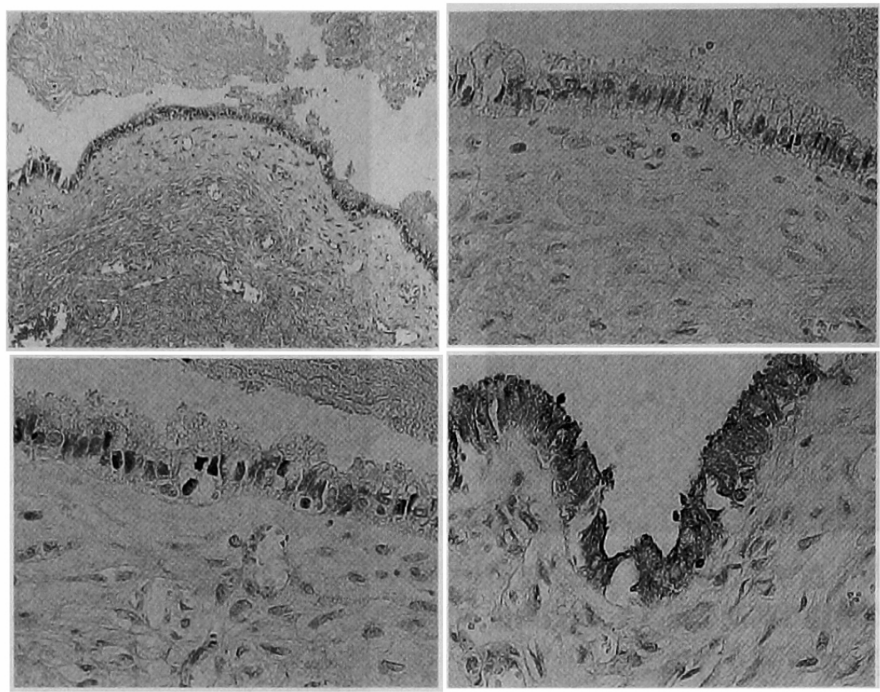

図 4 病理組織所見：a）H-E 染色 $(\times 100)$ ；䨢胞壁は粘液を含有する 単層立方上皮から成り,上皮の乳頭形成や配列の不整などの悪性所見 を認めない。間質の一部に㽗巣間質類似細胞や平滑筋細胞を認める。

b ) ER 免疫染色陽性 $(\times 400)$ 。 c ) PgR 免疫染色陽性 $(\times 400)$ ，d )

CA125 免疫染色陽性 $(\times 400)$.

\begin{tabular}{l|l}
$\mathrm{a}$ & $\mathrm{b}$ \\
\hline $\mathrm{c}$ & $\mathrm{d}$
\end{tabular}

表 1 腸間膜原発粘液性蒖胞腺腫の報告例

\begin{tabular}{|c|c|c|c|c|c|c|c|}
\hline 報告年度 & 報告者 & 性別 & 年夦 & 腫掦最大径 $(\mathrm{cm})$ & 部位 & 悪性度 & 畉巣間質類似組織の存在 \\
\hline 1988 & Banerjee & 女 & 58 & 7 & 肝瞉曲部腸間膜 & 良性 & 記載なし \\
\hline 1988 & Banerjee & 女 & 38 & 11 & 下行結腸間膜 & 境界悪性 & 記載なし \\
\hline 1988 & Cohen & 女 & 36 & 40 & 回腸間膜 & 良性 & 記載なし \\
\hline 1997 & McEvoy & 女 & 24 & 20 & $S$ 状結腸間膜 & 良性 & 記载なし \\
\hline 2000 & Felemban & 女 & 20 & 7.6 & 虫垂間膜 & 良性 & 記载なし \\
\hline 2004 & Talwar & 女 & 32 & 10 & 下行結腸間膜 & 境界悪性 & 記載なし \\
\hline 2004 & Kondi-Pafiti & 女 & 54 & 6 & 上行結腸間膜 & 良性 & 記载なし \\
\hline 2004 & Kondi-Pafiti & 女 & 45 & 6 & 記栽なし & 良性 & 記載なし \\
\hline 2004 & Kondi-Pafiti & 女 & 71 & 5.5 & 記載なし & 境界悪性 & 記載なし \\
\hline 2005 & 自験例 & 女 & 51 & 9 & 回盲部小腸間膜 & 良性 & あり \\
\hline
\end{tabular}

文献 6)〜11) より

考察

腸間膜の構成成分としては，中肧葉由来の単層偏平 な中皮細胞加成る腹膜の他に, 腹膜の間には結合組 織，脈管組織，脂肪組織，リンパ系組織，神経系組織 などが存在する．したがって，後腹膜や腸間膜にはこ れら種々の組織に由来した腫場が発生する。また，腸 間膜後後腹膜と発生学的，解剖学的に連続しており，
さらに腸壁とも解剖学的に連続しているため原発部位 を決めがたい場合がある．腫場が後腹膜に固定されず 可動性のあるものを腸間膜腫惕とし，腸管間膜起始部 にあり非可動性のものは後腹膜腫場とするが，両者の 中間型（移行型）も西る．同様に腸管と連続性のある 場合や，腫演が巨大で両者にまたがる場合にも発生部 位の判断は困難である1)。 
腸間膜烡胞性腫瘍の診断は，腹部超音波検査や CT, MRI などが有用であるが, 良悪性の鑑別を含めて確定 診断を得ることは困難である，腸間膜蕫胞性疾患の組

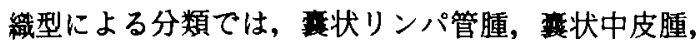
炎症性疮着による偽簧胞，発生途上に分離した腸管蒩 室・重複腸管などがあるか，この中ではリンパ管腫の 頻度が最も高い1). 良悪性の鑑別点として，哄胞壁の不 整や周囲組織への浸潤所見の他に，車腫の一部に石灰 化や充実性成分を認める場合は悪性の可能性が高いと されている213). 本症例では頻度的に腸間膜リンパ管隀 を疑ったが，術前の CT で，一部に充実性部分が疑わ れたため，悪性も否定できなかった。しかし摘出標本 で同部位は血腫や無数の小撉胞が集合した多房性の部 分であり、これらが画像上重なって充実性部分として 反映されたものであると考えられた，病理組織䛦断て

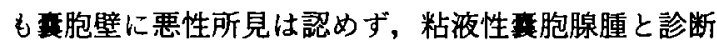
された。

粘液性亳胞腺腫は一般的に卵巣，虫垂，膵臓などに 発生する良性腫癔であり，腸間膜に発生するのは稀て ある。粘液性衰胞腺腫および悪性の黄胞腺癌が, 後腹 膜または腸間膜原発であると断定するには，卵单，虫 垂, 膵臓などの他臓器に同病変を認めず, 転移性病変 を否定し得ることが必須条件である゙55. 本症例では， 術前の画像診断や術中検索において卵巣などの他缄器 に原発となるような腫煬を認めなかった。さらに後腹 膜、卵巣，虫垂との境界は明瞭であることから，腸間 膜原発と判断した。医中誌（1983年から2004年，キー ワード：粘花性衰胞腺腫, 腸間膜萁腫) おうび Pubmed (期限なし, keyword：mucinous cystadenoma, mesenteric cyst）にてわれわれが検索した限りここれ らが後腹膜に発生した本邦報告例は若干認めるもの の,晹間膜原発となると本邦での報告例は未だ認めず, 海外でも 9 例の報告61 11)を認めるのみであった。これ に自験例を加えた10例（表 1）を総筧すると特別な好 発部位はないものの, 結腸間膜に発生することが多く， 小腸間膜に発生したものは自験例を含め 2例のみであ った。 また，すべて思春期以降の女性に発症しており， 男性での報告例は 1 例も認めなかった。

治療方針としては，悪性の場合を考慮して萁胞壁を 破壊せず，内容物を腹椌内に漏出することのないよう に注意しながら，外科的に完全摘出することが第 1 選 択となる。最近は腹腔鏡下手術の報告”もあるが, 悪性 であった場合の腹膜播種やポート部再発などの危険性 も指摘されている ${ }^{12}$. 本症例は腫瘍系が大きったこ
とや，悪性病変が否定てきなかったため，開腹による アプローチにて腫場を完全に摘出した。術後 1 年以上 が経過しているが, 再発徵候は認めていない.

後腹膜や腸間膜に発症する粘液性裹胞腺腫および䧶 胞腺癌は, 腫瘍の組織構成が本来の後腹膜や腸間膜に 存在しない粘液産生上皮の增殖からなるため, その発 生母地や組織発生に興味が持たれている.Roth ら ${ }^{(3)}$ は 後腹膜に発生した粘液性毫胞腺癌に卵巣間質類似組織 を認めたことから，異所性卵巣組織を発生母地の一つ として示唆しているが, 奇形腫, 重複腸管, 異所性卵 单, 内膜症などからの発生や, 腹膜体腔上皮の粘液化 生なども考えられている(14)-19\}. また，最近では腹膜警 入による二次性ミュラー管の粘液化生とする説が提示 され, 広く受け入れられている201 221. 本症例は奇形腫 の成分や重複腸管は確認されず, 病理組織学的に卵巣 類似成分を認め,さらに免疫染色で ER, PgR, CA125 が陽性であったことから，異所性卵巣や二次性ミュラ 一管組織由来の可能性が強く示唆された。

\section{結語}

回盲部小腸間膜から発生した非常に稀な粘液性襄胞 腺腫の 1 例を経験したので, 文献的考察を加え報告し た．腸間膜原発の粘液性襄胞腺腫は，これまで自験例 を含め10例の報告のみであり，本邦での報告例は認め ていない．思春期以降の女性て腸間膜に他蔵器と連続 性のない萋胞性病変を認めた場合は，本疾患も念頭に 入れて治療にあたる必要がある。

\section{女 献}

1）伊藤英明, 皇甫浩三, 永田直幹：腸間膜腫瘍。早 藤 弘編, 別冊日本臨林領域別症候群シリース, No.11, 腹膜・後腹膜・腸間膜・大網・小網・横隔 膜症候群, 第 1 版, 日本臨林社, 大阪, 1996, p169 $-171$

2）大山 司, 宗田滋夫, 橋本純平他：後腹膜に発生 した粘液性蘘胞腺腫の 1 例。日臨外医会誌 57 ： $2283-2287,1996$

3）松野直徒, 辻 孝彦, 内山正美地：後腹膜原発の 粘液性暴胞腺癌の 1 例. 日臨外会誌 $62: 542-$ 545,2001

4）高皇一郎, 中泉治雄, 村上真也他：徭腹膜原発粘 没㟟腫の 1 例. 臨外 $46: 1541-1544,1991$

5）四宮義浩, 并上裕, 高椋清他: Borderline malignancy を呈した後腹膜粘液言腫の 1 例. 日 臨外医会誌 $51 ： 1832-1835 ， 1990$

6) Banerjee R, Gough J : Cystic mucinous tumours of the mesentery and retroperitoneum : report of three cases. Histopathology 12:527-532, 1988 
7) Cohen I, Altaras $M$, Lew $S$, et al: Huge mesenteric mucinous cystadenoma in normal pregnancy. Obstet Gynecol $71: 1030-1032$, 1988

8) McEvoy AW, Cahill CJ, Jameson C : Mucinous cystadenoma of the sigmoid mesocolon: a previously unreported abdonimal tumour. Eur J Surg Oncol $23: 88-90,1997$

9) Felemban A, Tulandi T : Laparoscopic excision of a mesenteric cyst diagnosed preoperatively as an ovarian cyst. J Am Assoc Gynecol Laparosc $7: 429-431,2000$

10) Talwar A, Bell NJ, Nicholas D: Mucinous cystadenoma of colonic mesentery : report of a case. Dis Colon Rec $47: 1412-1414,2004$

11) Kondi-Pafiti A, Papadias K, Kairi-Vassilatou $E$, et al: Extraovarian mullerian-type cystic tumors of the female. A report of six cases and review of the literature. Eur J Gynecol Oncol $25: 657-659,2004$

12) Jin SC, Wei JL, Yun JC, et al : Laparoscopic resection of a primary retroperioneal mucinous cystedenoma : Report of a case. Surg Today $28: 343-345,1998$

13) Roth LM, Ehrlich CE : Mucinous cystadenocarcinoma of the retroperitoneum. Obst Gynecol $49: 486-488,1977$

14）永田二郎, 山内昌司, 寺部啓介他：後腹膜にみら $れ た$ mucinous cystadenoma of borderline malignancy $\sigma 1$ 例. 日外会誌 $88: 489-492$, 1987

15) Carabias E, Munoz HG, Dihmes FP, et al:
Primary mucinous cystadenocarcinoma of the retroperitoneum, Report of a case and literature review. Virchows Arch 426:641-645, 1995

16) Gotoh K, Konaga E, Arata A, et al : A case of primary retroperitoneal mucinous cystadenocarcinoma. Acta Med Okayama 46 : $49-52,1992$

17) Fujii S, Konishi I, Okamura H, et al : Mucinous cystadenocarcinoma of the retroperitonoum : A light and electron microscopic study. Gynecol Oncol $24: 103-112,1986$

18) Jorgensen LJ, Vibits $\mathrm{H}$ : Primary retroperitoneal mucinous cystadenocarcinoma a case report and review of the literature. APMIS 99 : 1055-1057, 1991

19) Melicow MM : Primary tumors of the retroperitoneum. A clinicopathologic analysis of 162 cases. Review of the literature and tables of classification. J Int Coll Surg 19:401-449, 1963

20) Lauchlan SC:Metaplasia and neoplasias of Mullerian epithelium. Histopathology $8: 543-$ 557,1984

21) Lauchlan SC: Review the secondary Mullerian system revisited. Int J Gynecol Pathol 13 : 7379,1994

22) Nomura $\mathrm{K}:$ Mucin histochemistry of ovarian mucinous cystadenomas expressing gastrointestinal characteristics. Pathol Int $45: 430-$ 435,1995

\title{
A MUCINOUS CYSTADENOMA ORIGINATED FROM MESENTERY-A CASE REPORT-
}

\author{
Norihisa KIMURA, Akihiko MURATA, Motoi KOYAMA, \\ Michihiro KURUSHIMA, Hajime MOROHASHI and Mutsuo SASAKI \\ Second Department of Surgery, Hirosaki University, School of Medicine
}

A 51-years-old woman received an examination complaining of the right abdominal pain. Abdominal computed tomography showed a homogeneous, non-enhanced cystic tumor of about $10 \mathrm{~cm}$ in diameter in the ileo-cecal mesentery. Colonoscopic study did not reveal mucosal lesion, nor luminal compression from outside. Angiography showed non-vascular area of the ileo-cecum. An operation was performed under the diagnosis of mesenteric lymphangioma. In operative findings, the tumor was $9 \times 8 \times 7 \mathrm{~cm}$ in size and existed in the ileo-cecal mesentery. We performed ileo-cecal resection including $100 \mathrm{~cm}$ of ileum, because the tumor had severe adhesion to the ileal wall. The resected specimen had multi-cystic lesion in part and contained green mucinous fluid. The histopathological diagnosis was mucinous cystadenoma. ER, PgR, and CA125 staining was positive that suggested the tomor originated from the female reproductive organ, such as ectopic ovarian tissue or secondary Mullerian system. We report a rare case of mucinous cystadenoma originated from ileo-cecal mesentery with a review of the literatures. 